\title{
ETHICS AND ARCHITECTURE: THE CASE OF ALBERT SPEER
}

\author{
Norman LILLEGARD \\ University of Tennessee, Martin, 38238 Tennessee, USA \\ E-mail:nlillega@utm.edu
}

Received 06 May 2014; accepted 25 August 2014

\begin{abstract}
It has been argued that there are obligations, or virtues and vices, that pertain uniquely to architectural practice. Thus Jack Sammons has argued that the moral failings of the Nazi architect Albert Speer were failings specific to him as an architect ( qua architect). I argue that Sammons' account misappropriates ideas about the virtues from Alasdair MacIntyre and for that and other reasons does not succeed. Nonetheless it may be possible to support the idea that there can be a specifically architectural ethics. I comment briefly on Heidegger's notion of 'dwelling' in trying to indicate what might be involved in such an ethics.
\end{abstract}

Keywords: aesthetics, dwelling, Escorial, Heidegger, hubris, ideology, MacIntyre, practices, Speer, virtue, Zeppelinfeld.

\section{Unique architectural ethics}

By devoting a discussion to 'ethics and architecture', we may seem to assume that there is something about being an architect, and/or something about architectural works, that has per se ethical import, an ethical dimension, ethical "meaning". There is, to be sure, an ethical dimension to any vocation or job, and any work product. It might be useful in some contexts to discuss ethics and selling stocks, ethics and ditch digging, ethics and (teaching) math. But in such cases, and many other such, we are unlikely to suppose that there is something intrinsic and unique to the activity that warrants ethical attention. A math teacher has many opportunities to do something right or wrong, virtuous or vicious; for example, he might assign a grade unfairly in order to extract sexual favors from a student. That action falls under various morally significant descriptions, but none of them make any essential reference to math, or to the teaching of math. The pertinent wrongness, or the vice, could just as easily be attributed to someone not engaged in teaching anything at all. Thus, exploiting others is wrong, and a disposition to treat others unfairly is a vice, and there are very many varying contexts in which such a vice might manifest itself.

But is there something contained in the work of architects that has an ethical dimension, no matter in what context they practice, something that arises only for architects, because of the very nature of their work? Some such idea has surfaced in a discussion of a particular architect (and that architect's ouvre) widely regarded as a moral failure, namely Albert Speer. Most people presumably would assess Speer's failure in a way similar to that I have chosen to describe the failure of my hypothetical math teacher; Speer seemed to be heedless of the impact his activities as architect and engineer were having on certain people. He seemed to be self-deceived with respect to his patron, Hitler. Such heedlessness and self-deception could have shown up just as well had he been in charge of, say, scheduling the Reich's train service. Speer's vices had nothing to do with being an architect per se.

The kind of account I'm attributing to 'most people' here, and that I am myself qualifiedly inclined to endorse, has been contested in two ways that I know of: on the one hand, some have supposed that there is something intrinsic not so much to being an architect as to being a bureaucrat/technician, such as Speer was, someone with technical skills that could be put to a variety of uses, good or bad. This view is found in, for example, the discussion of Speer by Hauerwas and Burrell (1977). On their view, Speer's moral failure is the consequence of being too completely absorbed in performing a technical function. He was a typical bur- 
eaucrat who 'treats ends as given, as outside his scope; his concern is with technique' as MacIntyre puts it in describing the managerial/technological modern type (MacIntyre 1984). That kind of failure is purportedly intrinsic to 'the bureaucratic type' or the 'pure technician'. Some of Speer's own remarks might indicate that he came to see himself in the light of this type of critique. The remedy would have been, he avers "... the self awareness of the individual human being as a counterpoise to technology" (Speer 1970). That is to say, the moral pitfalls that threaten a bureaucrat as he performs in accord with the technical requirements of a role can be avoided by revolting against that role and asserting oneself as an individual human being. But what sort of being is this 'individual human being?' Could it be a being who exists apart from all roles, who does not rely on any moral or religious or other cultural narratives to provide criteria for self- criticism? There are well known reasons which I will not rehearse here for denying that there could be such a human being. Apparently Speer did not see those reasons when he invoked the idea of the 'individual human being'. But what moral sources were available to Speer?

On the second view, expressed by Sammons, moral sources could have been found within the practice of architecture itself. In order to show how, Sammons cites various misgivings that Speer had regarding the "Hitler style" that he adopted. That style '... was 'pure "art of decadence"'(Speer 1970). How was Speer able to recognize this purported 'decadence?' Apparently by comparing the 'monumental kitsch' that he was producing to what he recognized, from his training and his immersion in the history of his discipline, as superior work, such as that found in the Escorial, with its "remarkable conciseness and clarity" (Speer 1970). Sammons proposes that Speer might have avoided his involvement with the 'decadent' third reich and its leader by taking more seriously what he knew as an architect (Sammons 2006).

At first sight Sammons' proposal seems most implausible. Speer sounds like an aesthete. It is not difficult to imagine an aesthete who is aesthetically repelled by brutality but nonetheless contributes to it while holding his nose, so long as doing so permits the indulgence of competing appetites. Why should we suppose that aesthetic criteria (for example, "conciseness and clarity"), have any power to encourage or dissuade, except in an accidental manner, where moral strength is required, or indeed have any moral import at all? This question can be seen as simply one way of putting a classical puzzle about the relationships (or lack thereof) between art and morality. We cannot begin to answer it in a way relevant to the case of Speer without reflecting a bit on architectural aesthetics and ethics.

\section{Ethics, aesthetics and architecture}

Many of the standard problems in the philosophy of the arts arise with a vengeance in discussions of architectural aesthetics. What could it mean, for example, to say that an architectural work means something, makes a statement, represents, or expresses something (a feeling, a belief, a fact)? The parallels to music have often been noted, but the essential practicality of works of architecture generates a significant contrast with music. Musical works, and most other works of art, can be ignored in a way that architectural works make impossible by their practical functions. That fact may create an opening for a discussion within architectural aesthetics of the connections between ethics and the arts. The positions on this last problem range from the view that works of art, whether literary, plastic, or musical could not have any moral bearings, to the view, represented perhaps most famously by Tolstoy, that the moral import of artistic works, (where 'moral value' is included in the religious view of the age) is the only thing that matters. Tolstoy should be thought of as rejecting 'aestheticism' in the arts, a rejection required by his insistence that works of art ought to matter (Cavell 1976). On this view, works of art must be more than pleasing, more than decoration or aesthetic manipulation of the senses, and thus, a fortiori, if works of architecture are or can be works of art, they must be something more than 'decorated sheds,' no matter how 'interesting' the decoration might be (Harries 1997). The 'something more' might be spelled out in terms that carry moral or religious import. And in fact that is what was happening in the early $20^{\text {th }}$ century.

\section{Architectural ideologies and ethics}

The very first sentence of the Bauhaus program sets the tone; "...the ultimate aim of all visual arts is the complete building," a gesamtkunstwerk that will '...shine with its abundance of light into the smallest objects of everyday life"(Wingler 1978). This amounted to a "declaration of war on the decorated shed"(Harries 1997: 329). All the arts had to be brought to earth, to everyday life. Given such a demand "...the unavoidable entanglement of architecture with the problems of living and dwelling that denies it the aesthetic completeness possible in the other arts becomes an asset that allows architecture to lead these arts out of their isolation... from life"(Harries 1997: 329, 330). A quasi religious view of life, a new secular religion, inspired Gropius and others. Gropius called for a "... rebirth [in architecture] of that spiritual unity which ascended to the miracle of the Gothic cathedrals" (Gropius et al. 1970). 
But this 'spiritual unity' was not to be "religious" in the usual historical sense, but an expression of socialist solidarity and technological mastery. In that way architecture might come to be seen as having 'ethical import,' at least as that is understood in that broad, more or less Aristotelian tradition in which ethical reflection begins with a view to human flourishing within a vital polis.

Could it be that by taking more seriously what he understood about architecture and its history, Speer might have discovered moral sources that would have protected him from Nazi ideology? The quotes above from Speer evince the aesthete who finds certain architectural styles to be vulgar. But such aestheticism, as already argued above, does not comport with any particular type of moral concern. Perhaps what is required, then, is something like what Gropius sought, an understanding of architecture as a source of spiritual unity.

In fact Sammons does mention something along these lines, but the inspiration is, we might say, from the right, not the (socialist, internationalist) left that attracted the Bauhaus followers. Speer's mentor, Heinrich Tessenow, held to the idea that '... style comes from the people ... there can be no true culture that is international. True culture comes only from the maternal womb of a nation'(Sammons 2006). It is easy to see how such ideas might encourage rather than dissuade someone tempted by Nazism, and Sammons notes that indeed Speer and other students "saw parallels between Tessenow's doctrine and the ideology of the National Socialists" (Sammons 2006). They had good reason to do so, despite the fact that Tessenow rejected the Nazis. The elevation of the "volk" and Herder-like ideas about the arts loom behind Tessenow's remarks, and such ideas undoubtedly figured into the origins and configuration of the Third Reich.

In fact, neither the left nor the right could be relied upon to equip a person with moral depth. It is apparent that both were likely to encourage shallowness and self deception or something quite a bit worse, as ideologies typically do. The program of the Bauhaus had, arguably, a socially manipulative aim hardly compatible with any view of morality that presupposes or requires individual freedom, and it was marked by arrogance. David Watkin traced a history of revolutionary ideology in $20^{\text {th }}$ century architecture characterized by contempt for the past and tradition, and an extraordinary belief in the ability of the architect to discern the real needs of people and to transform life for the better accordingly (Watkin 1977). This is not the place to examine this ideology in detail, but to say even this much about it makes the practice of architecture in accord with Bauhaus-like ideals look like a very du- bitable matter morally speaking. If there is any case to be made for a positive moral import to architecture, it will have to be made in other terms, taken neither from Tessenow, on the right, nor from the likes of Gropius or Bruno Taut on the left.

\section{Architecture, virtues and vices}

In searching for that case, we can look again at some of Speer's later misgivings about his work for Hitler. In describing the Escorial Speer remarked on the "... contrast with Hitler's architectural ideas: in the one case, remarkable conciseness and clarity, magnificent interior rooms, their form perfectly controlled; in the other [Hitler] case, pomp and disproportionate ostentation". (Speer 1970). Speer employs criteria remarkably reminiscent of those laid down for the designers of the Escorial. That work was the brainchild of Phillip the II of Spain, who gave instructions to his architect, Juan Buatista Toledo, directing that he should strive for "simplicity in the construction, severity in the whole, nobility without arrogance, majesty without ostentation" (el Escorial). Speer claimed that his own beginnings as an architect were consistent with the kind of modesty suggested in these remarks, but the "... estrangement from my beginnings was revealed in other ways than through the wildly excessive size of my buildings. They had become pure "art of decadence". Wealth, the inexhaustible funds at my disposal, but also Hitler's party ideology, had led along the path to a style which drew its inspiration rather from the show palaces of oriental despots" (Speer 1970). Sammons remarks on these developments thus; "He [Speer] did not just turn his back on reality; he brushed it away" (Sammons 2006). The implication is that if he had not done that, he would not have become Hitler's architect.

Let us suppose that Sammons is right; a Speer who was true to the purportedly superior architectural ideals with which he began would not have become Hitler's architect. Does that show that Speer's moral failings were simply, or mainly, failings qua architect? A simple thought experiment might contribute to answering this question. Imagine Speer with just one biographical variation; he had Phillip the II (in some possible $20^{\text {th }}$ century version) rather than Hitler as his patron. Grant that then Speer might have stuck to his own style, since it matched his patron's preferences, and ended up producing something like the Escorial, having been directed to produce 'nobility without arrogance, majesty without ostentation'. Would Speer have then been guaranteed freedom from his complicity with evil? I do not see how. It is not just that the court of Phillip offered its own opportunities for 
corruption, and that Phillip himself was no angel (we know what the low land protestants thought of Phillip. Pieter Breugel the younger aptly updated "the massacre of the innocents" in a painting with that title, in which Herod's men are represented as Spanish troops engaged in their own version of ethnic cleansing). Give all due credit to Phillip's taste. Does that necessarily guarantee absence of moral defects in his projects? No doubt the Escorial has merits the Zeppelinfeld lacks, but are those merits morally significant?

However, it might be replied that there are some moral overtones in the very language used here, in terms like 'ostentation', or 'pomp'. Let us concede this point for the moment in order to examine more closely what those overtones might come to. Let us overlook the difficulties involved in saying just how a building, like the Zeppelinfeld, could be an expression of excessive pride, or an expression of anything for that matter. Sammons takes the 'pomp' and related characteristics of Speer's work as indications of some kind of moral failing. What kind? It would have to be failure with respect to virtue/ vice. Excessive pride, hubris, is a vice. That vice could have been avoided if Speer had stuck to his own style. So the (moral) problem with Speer was that he did not do what being an architect could have taught him to do. That appears to be the gist of Sammons reasoning.

One obvious difficulty here is that virtue/vice concepts are concepts of multitrack dispositions in the agent, dispositions that show up in the various domains of a lived life, at home, at work, as a citizen, an artist etc. Thus they could not (logically) be dispositions that are unique to 'being an architect'. Nor could they be acquired simply in that role. But there is a bit more to be said.

In his discussion Sammons draws upon that most eminent of recent virtue theorists, Alasdair MacIntyre. MacIntyre argues that the virtues are necessary for practices. A practice is a shared activity with agreed upon standards, rules, criteria of various sorts, in terms of which success or achievement in that practice can be measured. Medicine, the law, government, the various arts including architecture, games and sports, are all practices. Consider a game like chess. Achievement in the practice of playing is measured by standards internal to it. Only by following the rules of this game, learning strategies limited by those rules, by absorbing some of its history, can one achieve goods that cannot (logically or conceptually) be achieved in any other way. Someone might play the game for money and win. Money can be a good, but it would be a good external to the practice, and is a good that could just as well be achieved in other ways. It could be achieved in some other 'game,' or it could be achieved by cheating.
What does this have to do with the virtues? The virtues, on MacIntyre's account, are those traits of persons that are required for the goods internal to practices to be achievable. The person who refuses to cheat (the just person) even when the chance presents itself, makes possible, for himself and others goods that can only be achieved in honest playing of games, honest research in physics or medicine, honest conduct of public affairs. The person in public office who risks her place (the courageous person) in promoting legislation that according to her lights will achieve some public good makes possible a good that is internal to a practice. Failures in these cardinal virtues of justice and courage, on the other hand, lead to the decay of practices and the demise of traditions. For example, the dishonesty involved in biased testing of neuroleptics has, arguably, caused a decline in the practice of psychiatry, and in achievement of its end, mental health.

How might this apply to the practice of architecture? To begin with, what are the goods internal to the practice of architecture? Unfortunately any attempt to answer is likely to be highly controversial. Here we see another feature of practices that MacIntyre emphasized, namely, that they have a history, and that history is often a history of conflict. There can be disagreement, within a practice, as to just what the standards are that constitute it at any point, as well as changes over time that reflect the working out of conflicts. But the changes are necessarily limited. The practice of the law, for example, has changed amid conflict, but there could not have been conflict over whether or not laws should be subject to suspension in any circumstances at the whim of an executive. That would be, in an enlightening analogy, a "game changer". Accordingly, it should always be possible to distinguish internal from external goods.

Part of Sammons critique of Speer consists in bringing out how external goods had replaced internal ones in his architectural career. It is not perfectly clear, but it appears that Sammons thinks that that fact itself shows exactly what Speer's moral failings amounted to. Speer was like the legal "hired gun" who doesn't care about justice so long as he gets paid. If Speer had the virtues necessary to sustain architectural practice, he would have stuck to his own style, and not submitted to Hitler for the sake of the power, etc. which doing so brought. So, what was wrong with Speer was that he failed to be a good architect.

This strikes me as very confused reasoning. Persons can fail in many different ways all at once. The thing that attracts attention to Speer is not just that he pursued external goods at the expense of internal goods (a very common failing, it must be admitted) but that he pursued them by aligning himself with a notorious 
criminal who was engaging in mass murder. That he did so shows dullness to character, or an exceptional degree of self deception, or a combination of these and other defects. Such lacks have no particular connection to 'being an architect'.

Sammons might have avoided this flimsy critique of Speer if he had paid attention to more of MacIntyre's discussion. MacIntyre always insisted that an understanding of virtues and vice in terms of practices was only very partial. In particular such an understanding cannot account for the place of the virtues in a "whole life". The account in terms of practices does not work at all for such 'whole life' virtues as constancy and integrity (ManIntrye 1984). Integrity refers to consistency with respect to the virtues throughout all aspects of a person's life. It is a kind of master virtue. The attempt to understand Speer's moral failings in terms of his lacks as an architect completely misses this. Speer's life, not just his life as an architect, was deeply corrupted.

\section{The ethical function of architecture}

While the discussion so far may close the door on Sammons' account of Speer's failings, it hardly ends the discussion of the relations between architecture and ethics, or for that matter the discussion of Speer's failings. Architects build places for people to live, work, shop, govern, display the arts, commemorate, study, worship etc. Where, how, when, out of what materials, can be ethically significant. Thus the architect might be thought of as having very particular obligations to build with a view to affordability, or environmental stability, or out of loyalty to a tradition, and so forth. Some of the obstacles to using the virtues/vices as an ethical 'handle' in thinking about ethics and architecture have already been addressed above, but there are other, act centered, approaches to ethics. Perhaps architects' obligations could be understood in terms of utility calculations. Faced with the task of designing and building, an architect might ask how what he does will produce the greatest happiness for the greatest number, or how it will maximize preferences. Alternatively, in some circumstances these obligations might be understood in more or less Kantian fashion, as strict duties. But the morally significant descriptions generated by these normative theories once again fail to locate anything unique to the architect's work. Thus the architect who is wasteful (of materials, space, etc.), may fail utilitarian tests for ethical correctness, but what constitutes the moral failing is the wastefulness, and non-architects can be wasteful.
There might, however, be some cases where the good to be maximized in a utilitarian calculation is in a sense specifically architectural. Suppose that people take pleasure in certain styles of building, even if not consciously. Pleasure maximization has occupied (for better or worse!) a central place in utilitarian thinking. The architect who understands how to give that pleasure by virtue of her immersion in the history and techniques of her discipline, is, we might say, capable of a unique ethical function. But people take 'pleasure' in such a variety of things, a sweet orange, a Mozart sonata, the fulfillment of a duty (sic!). Mill quickly realized some of the deep difficulties in the concept of pleasure, and tried to avoid them by postulating a distinction between "higher" and "lower" pleasures. The higher ones might even include pleasure taken in the fulfillment of a duty! Thus we run into a very characteristic problem in utilitarianism's attempts to ground ethics, namely, the content of 'utility' may turn out to be normatively loaded at the outset. To put it simply, it may turn out that what is 'useful' is what satisfies ethical norms that arise in human life independently of usefulness, so the utilitarian test may be useless (a very bad thing for anything utilitarian!). Related difficulties may arise for Kantian and other normative theories of ethics.

Modern moral philosophy, that is to say Humeian emotivism or expressivism in its many versions, Kantianism, and utilitarianism, have attempted to either ground most socially sanctioned norms, or show that there can be no such grounding. Difficulties with all of these views, including the one just mentioned in Mill, have induced some to deny that there can be such general theories of ethics. Thus some have endorsed the view that there are many irreducibly different ethical norms in different societies at different times. That kind of view tends to collapse into an incoherent relativism. Others have reacted by trying to recover some kind of natural law theory, or some account of the virtues that does not rely on discredited metaphysical teleology. Perhaps the most promising avenue here, particularly in the search for architectural ethics, would be something like a variant of the last two alternatives. What we need to find are more or less universal human traits, such as needs, desires, vulnerabilities, typical ways of experiencing self and world, that architecture can register or fulfill. We suppose a broadly Aristotelian framework, that is, we take it that ethics is concerned with conditions for the best kind of human life, and that it makes sense to speak of 'human life' in this way.

In 1951 Martin Heidegger gave a lecture to an audience composed mostly of architects, titled "Building Dwelling Thinking". Characteristically, he appeals to 
words and their histories in order to call attention to features of human life (dasein). Thus bauen (to build) has at its semantic core the idea of 'dwelling. 'Dwelling' names "the basic character of human being", and should be understood in contrast to the idea of being cast into infinite space. It refers to human being 'at home' in the world, and is the ground of building (architectural practice) that confers a sense of place (Heidegger 1971: 148). A sense of place is prior to abstract space in human experience. The word for space, raum, "... means a place cleared or freed for settlement and lodging" (Heidegger 1971: 156). Place requires boundaries, and in an obvious sense architects are in the business of producing boundaries, walls, roofs, etc. Heidegger hints at ways in which they can do this that will arise out of, and contribute to, 'dwelling' and thus to human life. Architecture that does that is fulfilling a kind of ethical function. This is not the place to discuss in any detail what these ideas might mean, or effectively have meant, for architectural practice. That task is taken up in a very balanced and insightful way by Karsten Harries in his book The Ethical Function of Architecture, cited above. One feature of Harries account is a stress on human limits and vulnerabilities, to decay, passage of time, death, as also setting limits to architectural practice of a kind that could bring some human fulfillment. The positive significance of these ideas for architecture is not easily or quickly stated, but it is a bit easier to indicate what is ruled out. Building that glorifies technology, building that claims to express and helps to institute gnosticizing claims about a new era freed from the limitations of the past, must be viewed with deep suspicion. And perhaps this takes us back to the moral failing of Speer, when his work is characterized (as it was by himself and Sammons) as guilty of hubris. The 'pomp' and 'ostentation' of his work were indeed incompatible with a practice of architecture that honors what is, on Heidegger's view, most distinctive and necessary in human living. But, as Harries puts it (once again summarizing Heidegger), "the integrated life has to give birth to and cannot simply be generated by the architect's work" (Harries 1997: 331). Speer's lack of integration was not and could not have been simply a failing qua architect. It was rooted in the general moral collapse of his life. Nonetheless, attention to good architecture could play a role in articulating what that integration might have come to.

\section{References}

Cavell, S. 1976. Must we mean what we say? Cambridge: Cambridge University Press. 193 p.

El Escorial [online], [cited 25 March 2014]. Available from Internet: http://en.wikipedia.org
Gropius, W.; Taut, B.; Behne, A. 1970. New ideas in architecture, in U. Conrads (Ed.). Programs and manifestoes in 20th century architecture. Cambridge MA: MIT Press.

Harries, K. 1997. The ethical function of architecture. Cambridge MA: MIT Press.

Hauerwas, S.; Burrell, D. 1977. Self deception and autobiography: reflections on Speer's "Inside the Third Reich", in Hauerwas, Truthfulness and tragedy. Notre Dame IN: University of Notre Dame Press.

Heidegger, M. 1971. Building dwelling thinking, in Poetry, language, thought, translated by A. Hofstadter. New York: Harper and Row.

MacIntyre, A. 1984. After virtue. Notre Dame IN: University of Notre Dame Press.

Sammons, J. 2006. Rebellious ethics and Albert Speer, in E. Katz (Ed.). Death by design. New York, NY: Pearson.

Speer, A. 1970. Inside the Third Reich. New York: Avon Books.

Watkin, D. 1977. Morality and architecture. Oxford: Clarendon press.

Wingler, H. 1978. The Bauhaus. Cambridge MA: MIT press.

\section{NORMAN LILLEGARD}

Professor emeritus of philosophy, University of Tennessee, Martin, 38238 Tennessee, USA. E-mail: nlillega@utm.edu

Visiting Professor of philosophy, Minzu University, Beijing, PRC. Visiting Professor of philosophy, Huazhong University of Science and Technology, Wuhan, PRC.

Author of works on ethics, including The Moral Domain (Oxford, 2010), aesthetics, the history of philosophy, including A Historical Introduction to Philosophy (Oxford, 2002, co-author James Fieser) and On Epicurus (Wadsworth, 2003), Kierkegaard, Wittgenstein, philosophy of religion, philosophy of language, philosophy of mind. 